УДК 342.9.03:340.130.5(470)

DOI dx.doi.org/10.24866/1813-3274/2019-3/100-104

\begin{abstract}
А. С. Кошель ${ }^{1}$, Дальневосточный федеральный университет, Владивосток, Россия

E-mail: koshel.as@dvfu.ru
\end{abstract}

\title{
НЕКОТОРЫЕ ВОПРОСЫ СОВЕРШЕНСТВОВАНИЯ ОТЕЧЕСТВЕННОГО ЗАКОНОДАТЕЛЬСТВА ОБ АДМИНИСТРАТИВНОЙ ОТВЕТСТВЕННОСТИ
}

Аннотация. В статье кратко рассмотрены перспективы реформы отечественного законодательства об административной ответственности, озвученные в докладе на круглом столе «Законодательство об административной ответственности: современное состояние, перспективы развития», состоявшемся в Дальневосточном федеральном университете 9 апреля 2019 г. Кодекс Российской Федерации об административной ответственности претерпел на 2019 г. уже более 3000 изменений (правок), а нормы об административной ответственности на сегодня содержатся в большом количестве федеральных законов, сам Кодекс содержит большое количество бланкетных норм, а правоприменители отличаются слабыми знаниями законодательства, что в совокупности затрудняет правоохранительную функцию законодательства об административной ответственности. Автором на основе материалов судебной и правоприменительной практики предлагается внесение в концепцию реформы законодательства об административной ответственности инициатив по введению специального общественного квалификационного экзамена для правоприменителей законодательства об административной ответственности; установлению строгой категории вины юридического лица и вины должностного лица, учитывающей избежание наказания двух лиц за совершение одного административного проступка; либерализации административной ответственности по административным проступкам, совершённым впервые, вплоть до ограничения такой ответственности замечанием. Автор убеждён, что реформа федерального и регионально-

\footnotetext{
${ }^{1}$ Алексей Сергеевич Кошель, помощник председателя Комитета Государственной Думы Федерального Собрания Российской Федерации по регламенту и контролю, кандидат политических наук, доцент, доцент кафедры конституционного и административного права Юридической школы Дальневосточного федерального университета, Владивосток, Россия.

Для ицтирования: Кошель А. С. Некоторые вопросы совершенствования отечественного законодательства об административной ответственности // Азиатско-Тихоокеанский регион: экономика, политика, право. 2019. № 3. С. 100-104.
}

(C) Кошель А.С., 2019 
го законодательства об административной ответственности в Российской Федерации должна носить комплексный характер и должна быть направлена не на карательную функцию норм, а на правоохранительную, с целью избежания злоупотребления правоприменителями своими полномочиями и создания условий для нормализации функционирования коммерческих и некоммерческих организаций в Российской Федерации, повышения уровня защищенности бизнес-климата в стране.

Ключевые слова: административная ответственность, реформа, КоАП, законодательство об административной ответственности, административное правонарушение, административная ответственность юридических лиц, административное наказание.

Alexey S. Koshel ${ }^{1}$, Far Eastern Federal University, Vladivostok, Russia E-mail: koshel.as@dvfu.ru

\section{SOME ISSUES OF IMPROVING THE RUSSIAN LEGISLATION ON ADMINISTRATIVE RESPONSIBILITY}

Abstract. The article reviews the prospects of reforming the legislation on administrative responsibility based on the round table report "Legislation on administrative responsibility: modern state, development prospects" in the Far Eastern Federal University on April 9, 2019. As of 2019, over 3000 changes (amendments) had been introduced into the Russian Federation Code on administrative responsibility; administrative responsibility norms can nowadays be found in many federal laws; the Code contains a lot of blanket norms; law enforcers have an insufficient knowledge of the legislation thus hindering the law-enforcing function of the legislation on administrative responsibility. Based on the material of court and law-enforcement practices, it is suggested to introduce the initiatives on implementing a special public qualifying examination of the law-enforcers for the legislation of administrative responsibility, strict categories of the corporate body's guilt and office holder's guilt that would avoid punishing two people for committing the same administrative offence, liberalization of administrative responsibility on administrative offences committed first time including reducing this responsibility to admonition. The author of the article is sure that reforming the federal and regional legislations on administrative responsibility in the Russian Federation has to be complex and switch its function from punishment to preventing the law enforcers from misusing their authority; it

\footnotetext{
${ }^{1}$ Alexey S. Koshel, , Deputy of the Chairman of the State Duma of Russian Federal Assembly Committee in charge of regulations and control, Candidate of Political Sciences, Associate Professor, Assistant Professor of the Department of Constitutional and Administrative Law, School of Law, FEFU, Vladivostok, Russia.

For citing: Koshel A. S. Some issues of improving the russian legislation on administrative responsibility // Asia-Pacific RIM: Economic, Politics, Law. 2019. № 3. P. 100-104.
} 
also has to create the conditions for normalizing the functioning of commercial and noncommercial organizations in the Russian Federation and increase the level of business climate protection in the country.

Key words: administrative responsibility, reforms, Code on Administrative Offences, administrative responsibility legislation, administrative offense, administrative responsibility of corporate bodies, administrative punishment.

Принятый в 2001 году Кодекс об административной ответственности усилил подведомственность судов по рассмотрению дел об административных правонарушениях с четырёх до ста составов по сравнению с КоАП РСФСР 1984 г. Вместе с тем это всё равно ничтожно малое количество дел из общего массива законодательства об административной ответственности. Всего на сегодня КоАП РФ включает более 1500 составов административных правонарушений, рассматриваемых 58 органами государственной власти.

В отечественной правовой доктрине сегодня неоднократно отмечается необходимость не только и не столько модификации действующего КоАП, и так претерпевшего уже более 3000 изменений, но и вообще принятия нового Кодекса. На сегодня КоАП РФ содержит большое количество бланкетных норм, что не позволяет правоприменителям (значительная часть которых - это сотрудники органов внутренних дел, различных федеральных служб, осуществляющих надзор) однозначно и качественно принимать решения по привлечению лиц к административной ответственности. Кроме того, наличие у надзирающих и правоохранительных органов специальных показателей эффективности, выраженных в количестве дел о привлечении к административной ответственности, также вызывает глубокие сомнения. Известно, что наличие подобных показателей, по мнению федеральных органов исполнительной власти, призвано исключить коррупционные явления в правоохранительных органах. Но на деле такие нормы, исключая произвол административных органов, связанный с коррупционными фактами, приводят к иного рода произволу органов власти.

Важнейшим шагом на пути построения законности и соблюдения конституционности в административном процессе явилось принятие в 2015 г. Кодекса административного судопроизводства. Особый порядок допуска (наличие юридического образования) представителей административного истца в административный процесс отстаивали многие видные юристы, среди которых представители Ассоциации юристов России, председатель комитета Государственной Думы по государственному строительству и законодательству Павел Владимирович Крашенинников, полномочный представитель Правительства Российской Федерации в Верховном и 
Конституционном Судах Российской Федерации Михаил Юрьевич Барщевский и многие другие.

Внесенный в Государственную Думу в 2017 г. и отозванный в прошлом году законопроект об обязательном юридическом цензе, экзамене на право представлять интересы сторон в суде закреплял не только наличие требования к квалификации представителя, но и порядок подтверждения такой квалификации. Предлагалось одним из таких экзаменационных органов определить Ассоциацию юристов России. На сегодня специальный ценз для представителей в суде действует только в отношении дел, рассматриваемых Конституционным Судом Российской Федерации, а также в порядке уголовного и административного процесса, а с 1 октября 2019 г. такие ограничения в соответствии с принятым законом о процессуальной реформе должны появиться во всех видах процесса, за исключением дел, подведомственных мировому и районному суду. Однако и это является спорным - большинство гражданских дел разбираются в первой инстанции именно этими судами. И действительно, юридический ценз для представителей в суде важен с целью поддержания доверия к судебной системе, правильного и быстрого рассмотрения дел в суде.

В дополнение к этому я бы рекомендовал всем правоприменителям из числа сотрудников органов государственной власти, привлекающим лиц к административной ответственности, пройти специальную переподготовку по знанию законодательства об административной ответственности; и в дополнение к тому ввести специальные экзамены на допуск к назначению на должность для лиц, это законодательство применяющих. Быть может, следует передать право приёма таких экзаменов как раз юридическому сообществу в лице Ассоциации юристов России. Несомненно, такой подход повысит не только ответственность лиц, применяющих нормы законодательства об административной ответственности, но и усилит доверие общества к правоохранительным органам в целом.

В доктрине отмечается и важность определения самого понятия административной ответственности. К примеру, сегодня многие дела разбираются судом и административными органами по наличию формального состава, без определения виновности лица в совершении административного правонарушения. Это, в первую очередь, дела, разрешаемые в отношении споров о защите информации, где Роскомнадзор может привлечь должностное лицо, которое не имело и не могло иметь возможности принять меры к исключению возможности совершения юридическим лицом противоправных деяний. Возникают спорные ситуации и в делах о валютном контроле. К примеру, мы недавно столкнулись с казусом, в соответствии с которым налоговый резидент несёт ответственность за бездействие со стороны своего иностранного контрагента, абсурдным, на мой взгляд. По сути своей подобные нормы приводят законодательство об административной ответственности к репрессивному характеру. 
Законодательство у нас динамичное, особенно это касается административной ответственности, и от правильности его применения зависит не только уровень правосознания Общества, но и многие свободы, важнейшей из которых является свобода экономической деятельности.

Возможно, стоит исключить административную ответственность лиц, впервые привлекаемых по определённым составам правонарушений, с целью повышения превентивного характера норм об административной ответственности. И в то же время усилить ответственность за повторные правонарушения. Вот это действительно была бы реформа!

В заключение хотелось бы резюмировать высказанные амбициозные предложения к концепции реформы законодательства об административной ответственности, а именно:

1) Введение в законодательство об административной ответственности чёткой и стройной категории вины юридического лица и должностных лиц юридического лица с целью недопущения применения административной ответственности к лицам, которые не могли принять мер к несовершению административного проступка;

2) Либерализация ответственности за впервые совершённые административные правонарушения по определенным составам с целью повышения превентивной функции норм об административной ответственности и недопущения произвола административных органов;

3) Введение специального экзамена (по аналогии с квалификационным экзаменом на статус судьи) для должностных лиц органов исполнительной власти, которым поручается рассматривать дела об административных правонарушениях, с целью повышения доверия общества к применяемым мерам ответственности, а также рассмотрение возможности создания для принятия этих экзаменов специальных квалификационных комиссий из числа представителей общественности, в частности Ассоциации юристов России.

Реформирование отечественного законодательства об административной ответственности поможет создать благоприятные условия для функционирования коммерческих и некоммерческих организаций и улучшит бизнес-климат в стране. 